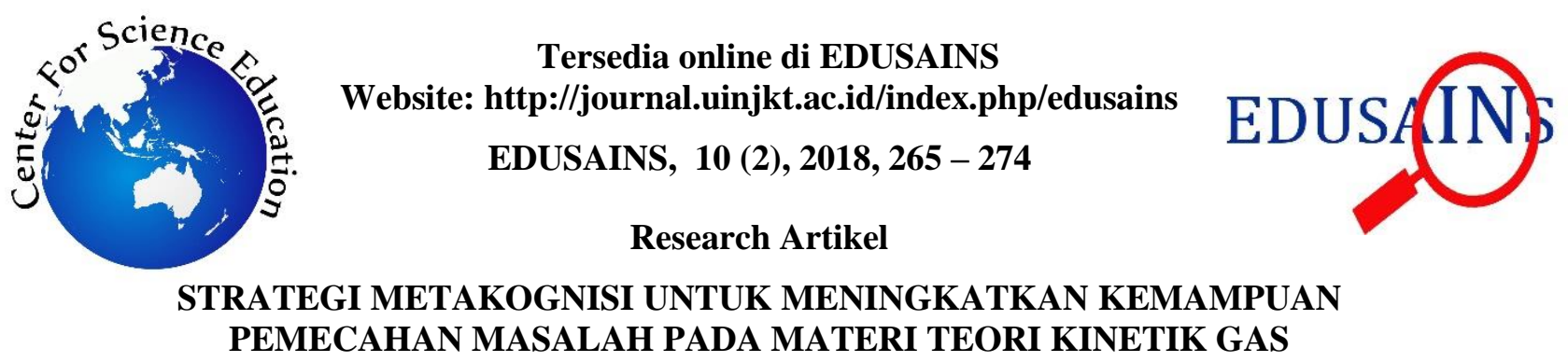

\title{
THE STRATEGY OF METACOGNITION TO IMPROVE PROBLEM SOLVING COMPETENCY IN KINETIC THEORY OF GASES
}

\author{
Nur Arviyanto Himawan, Winarti \\ Universitas Islam Negeri Sunan Kalijaga, Indonesia \\ arvians21@gmail.com
}

\begin{abstract}
Metacognition is the most important part of problem solving, in which students control consciously the cognition activity in planning, monitoring and evaluating the physics problem solving. The purpose of this research is to know the influence of metacognition strategies to problem solving ability. This research is quasi experiment with nonequivalent control grup design. The sample consist of class XI MIPA 1 as a control class and XI MIPA 2 as experiment class. The test technique used is form of a description sheet to obtain problem solving skill data, while the nontest technique used is form of an observation sheet to obtain learning activity data. Problem solving skill data is analyzed by quantitative method using descriptive statistic. The result of research indicates that there is an influence of metacognition strategies to student problem solving skill. There is an increase in problem solving ability in experiment class with 0.61 of $\mathrm{N}$-Gain grade (medium), which is higher than control class. Observation result indicates that student learning activity in experiment class is higher than that in control class.
\end{abstract}

Keywords: Metacognition Strategy; Problem Solving Skill; Kinetic Theory of Gas

\begin{abstract}
Abstrak
Metakognisi merupakan bagian penting dalam proses pemecahan masalah, dimana siswa secara sadar mengontrol aktivitas kognisi dalam merencanakan, memantau serta mengevaluasi pemecahan masalah fisika. Penelitian ini bertujuan untuk mengetahui pengaruh strategi metakognisi terhadap kemampuan pemecahan masalah. Penelitian ini merupakan eksperimen semu (quasi experiment) dengan nonequivalent control grup design. Sampel terdiri dari kelas XI MIPA 1 sebagai kelas kontrol dan XI MIPA 2 sebagai kelas eksperimen. Digunakan teknik tes berupa lembar soal uraian untuk memperoleh data kemampuan pemecahan masalah, dan teknik non tes berupa lembar observasi untuk memperoleh data tentang aktivitas belajar. Data kemampuan pemecahan masalah dianalisis dengan metode kuantitatif menggunakan statistik deskriptif. Hasil penelitian menunjukkan bahwa terdapat pengaruh strategi metakognisi terhadap kemampuan pemecahan masalah siswa. Terdapat peningkatan kemampuan pemecahan masalah pada kelas eksperimen dengan nilai $N$-Gain sebesar 0,61 (sedang), yang lebih tinggi dibandingkan kelas kontrol. Hasil observasi menunjukkan aktivitas belajar siswa kelas eksperimen lebih tinggi dibandingkan kelas kontrol.
\end{abstract}

Kata Kunci: Strategi Metakognisi; Kemampuan Pemecahan Masalah; Teori Kinetik Gas

Permalink/DOI: http://dx.doi.org/10.15408/es.v10i2.8021

\section{PENDAHULUAN}

Tujuan dari proses pembelajaran adalah menghasilkan siswa yang memiliki pengetahuan dan keterampilan dalam memecahkan masalah. Latipah (2012) menyatakan bahwa pemecahan masalah diartikan sebagai penggunaan (yaitu mentransfer) pengetahuan dan keterampilan yang sudah ada untuk menjawab pertanyaan yang belum terjawab atau situasi yang sulit. Kemampuan pemecahan masalah sangat penting dalam pembelajaran fisika karena menjadi tolak ukur seberapa jauh siswa dalam menguasai dan mengimplementasikan ilmu yang didapatkan untuk mencari solusi pada suatu permasalahan. Namun 
kenyataannya, pemecahan masalah menjadi salah satu kendala dalam proses pembelajaran fisika, terutama pada materi yang sifatnya abstrak seperti teori kinetik gas. Mahmudah (2013) menyatakan materi teori kinetik gas merupakan materi yang sulit untuk dipahami karena karakteristik materi tersebut bersifat abstrak dan tidak bisa diamati secara visual dan membutuhkan pemahaman yang menyeluruh dalam konsepnya agar tidak melakukan kesalahan dalam menyelesaikan permasalahan terkait materi tersebut.

Mahmudah (2013) mengungkapkan beberapa jenis kesalahan yang dilakukan siswa dalam menyelesaikan soal pada materi teori kinetik gas, seperti kesalahan dalam menerjemahkan soal dan kesalahan dalam penggunaan strategi atau cara penyelesaian. Penyebabnya adalah siswa kurang teliti dan belum dapat membedakan penggunaan simbol-simbol fisika. Hal ini sejalan dengan hasil wawancara yang menunjukkan bahwa siswa MAN 4 Bantul mengalami kesulitan dalam memahami permasalahan dan merencanakan strategi penyelesaian permasalahan. Siswa kesulitan dalam menghubungkan data-data yang ada dalam permasalahan dengan persamaan yang akan digunakan untuk menyelesaikan permasalahan tersebut.

Berdasarkan observasi yang dilakukan, ketika guru memberikan latihan soal, siswa cenderung menunggu guru memberikan penjelasan mengenai apa saja yang diketahui dalam soal serta bagaimana cara pengerjaannya. Selanjutnya, siswa hanya perlu melanjutkan penyelesaian soal tersebut. Hal ini menunjukkan bahwa kegiatan pembelajaran yang berlangsung belum memfasilitasi keterampilan berpikir dalam memecahkan masalah karena siswa tidak dilatih dalam mengontrol aktivitas kognisinya.

Kemampuan pemecahan masalah berkaitan langsung dengan proses pengontrolan aktivitas kognitif siswa secara sadar, atau yang biasa dikenal dengan metakognisi. Pengontrolan aktivitas tersebut yaitu siswa dapat merencanakan, memantau serta mengevaluasi proses pemecahan masalah fisika. Proses pemecahan masalah berhubungan dengan langkah pemecahan masalah. Terdapat banyak ahli yang memberikan pendapatnya mengenai langkah-langkah dalam menyelesaikan suatu permasalahan, salah satunya George Polya. Menurut Anggo (2011), langkah pemecahan yang dikemukakan George Polya mengarahkan kepada kesadaran dan pengaturan siswa terhadap proses yang dilaksanakan untuk memperoleh solusi yang tepat. Hal ini berarti terdapat kaitan erat antara metakognisi dan langkah pemecahan masalah yang diajukan George Polya. George Polya (1973) mengajukan langkah-langkah yang sistematis agar siswa dapat memecahkan suatu masalah dengan baik, yaitu memahami permasalahan, merencanakan penyelesaian permasalahan, menyelesaikan permasalahan sesuai rencana, serta peninjauan kembali. Langkahlangkah pemecahan masalah yang dikemukakan Polya telah menjadi dasar bagi pengembangan strategi metakognisi (Anggo, 2011).

Flavell (1979) menyatakan bahwa metakognisi terdiri dari dua komponen yaitu pengetahuan metakognisi (metacognition knowledge) dan pengalaman metakognisi (metacognition experience). Pengetahuan metakognisi mencakup pengetahuan tentang strategi, tugas, dan pengetahuan diri (Anderson \& Krathwohl, 2015). Pengalaman metakognisi mengacu pada aktivitas metakognisi yang dapat membantu seseorang mengontrol pemikiran atau pembelajarannya, yaitu: merencanakan, memantau, dan mengevaluasi (Schraw \& Moshman, 1995). Dari dua komponen tersebut, dapat dipahami bahwa ketika mempelajari metakognisi maka seakan-akan berdiri di luar kepala dan mencoba merenungkan proses berpikir yang dilakukan (Nugrahaningsih, 2012)

Berdasarkan hasil wawancara, pembelajaran yang dilakukan belum memfasilitasi metakognisi siswa. Strategi pembelajaran yang digunakan belum mengajak siswa untuk mengevaluasi proses belajarnya. Hal ini berarti siswa belum melatih pengalaman metakognisinya. Padahal menurut hasil penelitian yang dilakukan oleh Wahyuddin (2016), semakin baik metakognisi yang dimiliki oleh siswa maka kemampuan pemecahan masalah bagi siswa tersebut juga semakin tinggi. Oleh karena itu, pembelajaran yang dapat memfasilitasi metakognisi siswa sangat penting dalam melatih kemampuan pemecahan masalah fisika. 
Metakognisi siswa dapat difasilitasi dengan berbagai cara, salah satunya melalui strategi pembelajaran. Blakey \& Spence (1990), mengemukakan strategi untuk meningkatkan metakognisi yaitu, mengindentifikasi apa yang diketahui dan apa yang tidak diketahui, berbicara tentang berpikir, membuat jurnal berpikir, membuat perencanaan dan regulasi diri, melaporkan kembali proses berpikir dan evaluasi diri. Hasil penelitian Jayapraba (2013) menunjukkan strategi tersebut terbukti mampu meningkatkan kesadaran metakognisi siswa.

Berdasarkan penjabaran di atas, strategi pembelajaran metakognisi perlu diterapkan untuk memberdayakan metakognisi yang peran penting dalam proses pemecahan masalah teori kinetik gas. Pengetahuan metakognisi berguna dalam proses pembelajaran, dimana siswa akan mampu mempersiapkan strategi dalam menghadapi tugastugas kognitif, menyadari sejauh mana ketercapaian belajar dan memilih solusi atas kesulitan belajar yang dihadapi dalam mempelajari materi teori kinetik gas. Sedangkan pengalaman metakognisi akan mendorong siswa secara sadar mengontrol aktivitas kognisi dalam merencanakan, memantau serta mengevaluasi pemecahan masalah teori kinetik gas. Oleh karena itu, penelitian ini bertujuan untuk mengetahui pengaruh strategi metakognisi terhadap kemampuan pemecahan masalah siswa pada materi teori kinetik gas.

\section{METODE}

Penelitian ini merupakan penelitian eksperimen semu (quasi experiment) dengan nonequivalent control grup design. Variabel dalam penelitian ini meliputi variabel bebas berupa strategi pembelajaran metakognisi dan variabel terikat berupa kemampuan pemecahan masalah. Populasi dalam penelitian ini adalah siswa kelas XI MIPA MAN 4 Bantul tahun pelajaran 2016/2017. Teknik pengambilan sampel yang digunaka adalah sampling jenuh. Kelas XI MIPA 1 yang terdiri dari 32 siswa menjadi kelas kontrol, sedangkan kelas XI MIPA 2 yang terdiri dari 31 siswa menjadi kelas eksperimen. Instrumen yang digunakan dalam penelitian ini berupa lembar soal uraian dan lembar observasi. Lembar soal uraian pretest-posttest digunakan untuk memperoleh data kemampuan pemecahan masalah siswa, dan lembar observasi digunakan untuk memperoleh data pendukung penelitian tentang aktivitas siswa dalam mengikuti pembelajaran teori kinetik gas dengan strategi metakognisi dan strategi ekspositori. Data kemampuan pemecahan masalah dianalisis dengan metode kuantitatif menggunakan statistik deskriptif.

Analisis deskriptif yang digunakan dalam penelitian ini adalah: Pertama, penyajian data berupa tabel dan diagram plot. Kedua, ukuran tendensi sentral yang berupa nilai mean, median, dan modus. Ketiga, ukuran dispersi yang terdiri dari daerah jangkauan (range) dan standar deviasi (deviation standard). Keempat, ukuran letak yang berupa kuartil.

Peningkatan kemampuan pemecahan masalah siswa diketahui dengan melihat nilai $\mathrm{N}$ Gain berdasarkan persamaan berikut:

$$
\mathrm{N}-\text { Gain }=\frac{\text { posttest score }- \text { pretest score }}{\text { maximum possible score }- \text { pretest score }}
$$

Setelah mendapatkan nilai N-Gain, selanjutnya diklasifikasikan menurut Richard R. Hake (1998) seperti yang ditampilkan tabel 1 berikut.

Tabel 1. Klasifikasi $N$-gain

\begin{tabular}{cc}
\hline Nilai $\boldsymbol{N}$-Gain & Klasifikasi \\
\hline $0,70<\mathrm{N}$-gain $\leq 1,00$ & Tinggi \\
$0,30<\mathrm{N}$-gain $\leq 0,70$ & Sedang \\
$\mathrm{N}$-gain $\leq 0,30$ & Rendah \\
\hline
\end{tabular}

\section{HASIL DAN PEMBAHASAN}

\section{Hasil Kemampuan Pemecahan Masalah}

Berdasarkan tabel 2, ukuran tendensi sentral kemampuan pemecahan masalah pada kedua kelas mengalami perubahan. Terlihat bahwa peningkatan ukuran tendensi sentral kelas eksperimen lebih tinggi dibanding kelas kontrol. Perubahan skor kemampuan pemecahan masalah dapat pula dilihat melalui ukuran dispersi yang disajikan pada tabel 3 . Ukuran dispersi ini menunjukkan ukuran penyebaran data. Range dan standar deviasi pada kedua kelas mengalami peningkatan setelah diberikan perlakuan. Kelas eksperimen memiliki perubahan range atau rentang antara skor maksimum dan skor minimun yang lebih kecil dibandingkan kelas kontrol. Selain itu, adanya peningkatan deviation standard dari kelas 
eksperimen dan kelas kontrol memperlihatkan nilai yang semakin beragam atau heterogen. Apabila dibandingkan, deviation standard kelas eksperimen setelah diberikan perlakuan lebih rendah dari kelas kontrol. Hal tersebut menunjukkan distribusi nilai kemampuan pemecahan masalah kelas eksperimen lebih homogen dibandingkan kelas kontrol.

Perubahan ukuran letak kedua kelas yang disajikan pada tabel 4 juga memperlihatkan perubahan skor kemampuan pemecahan masalah kedua kelas tersebut. Ukuran letak ketiga kuartil membagi data skor menjadi 4 bagian. Berdasarkan data tersebut dapat diketahui bahwa ukuran letak kelas eksperimen lebih tinggi dibandingkan kelas kontrol. Lebih jelas, penyebaran data skor pretest dan posttest kemampuan pemecahan masalah disajikan dalam diagram plot pada Gambar 1.

Pada gambar 1 (a) dan 1 (b), sumbu $\mathrm{x}$ merupakan skor pretest, sumbu y merupakan skor posttest, garis vertikal merupakan rata-rata skor pretest, dan garis horizontal merupakan rata-rata skor posttest. Sedangkan titik-titik yang ada pada gambar 1 (a) dan 1 (b) merupakan skor pretest dan posttest. Beberapa titik menunjukkan sebagian siswa yang memperoleh skor pretest rendah ternyata memperoleh skor posttest yang cukup tinggi. Hal ini menunjukkan bahwa pembelajaran yang diberikan memberikan pengaruh terhadap peningkatan kemampuan pemecahan masalah siswa pada kedua kelas. Namun apabila dibandingkan, kelas eksperimen memiliki peningkatan yang lebih tinggi dibanding kelas kontrol. Hal ini dikarenakan siswa kelas eksperimen lebih terlatih dalam merancang, memantau dan mengevaluasi proses pemecahan masalah yang mereka lakukan.

Selanjutnya, pada gambar 2 (a) dan 2 (b) dapat terlihat sebaran skor pretest dan $N$-Gain pada kedua kelas.

Sumbu x pada gambar 2 (a) dan 2 (b) merupakan skor pretest, sumbu y merupakan $\mathrm{N}$ Gain, garis vertikal merupakan rata-rata skor pretest, dan garis horizontal merupakan rata-rata $N$ Gain. Sedangkan titik-titik yang ada pada gambar 2 merupakan skor pretest dan $N$-Gain. Berdasarkan gambar 2 gambar 2 (a) dan 2 (b), skor $N$-Gain kedua kelas bernilai positif. Hal ini berarti kemampuan pemecahan masalah setiap siswa mengalami peningkatan setelah diberikan perlakuan.

\section{a. Ukuran Tendensi Sentral}

Tabel 2. Deskripsi Nilai Ukuran Tendensi Sentral Kemampuan Pemecahan Masalah

\begin{tabular}{ccccccc}
\hline \multirow{2}{*}{ Kelas } & \multicolumn{3}{c}{ Pretest } & \multicolumn{3}{c}{ Posttest } \\
\cline { 2 - 7 } & Mean & Median & Modus & Mean & Median & Modus \\
\hline Eksperimen & 2,74 & 2,00 & 0 & 41,39 & 42,00 & 42 \\
Kontrol & 3,75 & 3,50 & 0 & 31,69 & 34,50 & 43 \\
\hline
\end{tabular}

\section{b. Ukuran Dispersi/ Penyebaran}

Tabel 3. Deskripsi Nilai Ukuran Dispersi Kemampuan Pemecahan Masalah

\begin{tabular}{ccccccccc}
\hline \multirow{2}{*}{ Kelas } & \multicolumn{4}{c}{ Pretest } & \multicolumn{4}{c}{ Posttest } \\
\cline { 2 - 9 } & \multirow{2}{*}{ Min } & \multirow{2}{*}{ Max } & Range & $\begin{array}{c}\text { Deviation } \\
\text { Standard }\end{array}$ & Min & Max & Range & $\begin{array}{c}\text { Deviation } \\
\text { Standard }\end{array}$ \\
\hline Eksperimen & 0 & 12 & 12 & 2,556 & 24 & 53 & 29 & 7,210 \\
Kontrol & 0 & 12 & 12 & 3,501 & 13 & 43 & 30 & 8,902 \\
\hline
\end{tabular}

\section{c. Ukuran Letak}

Tabel 4. Deskripsi Nilai Ukuran Letak Kemampuan Pemecahan Masalah

\begin{tabular}{ccccccc}
\hline \multirow{2}{*}{ Kelas } & \multicolumn{3}{c}{ Pretest } & \multicolumn{3}{c}{ Posttest } \\
\cline { 2 - 7 } & $\boldsymbol{Q}_{\boldsymbol{1}}$ & $\boldsymbol{Q}_{\mathbf{2}}$ & $\boldsymbol{Q}_{3}$ & $\boldsymbol{Q}_{\boldsymbol{1}}$ & $\boldsymbol{Q}_{\mathbf{2}}$ & $\boldsymbol{Q}_{3}$ \\
\hline Eksperimen & 1,00 & 2,00 & 4,00 & 36,00 & 42,00 & 47,00 \\
Kontrol & 0,25 & 3,50 & 6,00 & 23,25 & 34,50 & 39,00 \\
\hline
\end{tabular}




\section{d. Hasil N-Gain Kemampuan Pemecahan Masalah}

\begin{tabular}{cccccc}
\multicolumn{6}{c}{ Tabel 5 . Hasil $N$-Gain Kemampuan Pemecahan Masalah } \\
\hline Kelas & $\mathbf{N}$ & Terendah & Tertinggi & Rata-rata & Kriteria \\
\hline Eksperimen & 31 & 0,33 & 0,79 & 0,61 & Sedang \\
Kontrol & 32 & 0,17 & 0,63 & 0,45 & Sedang \\
\hline
\end{tabular}

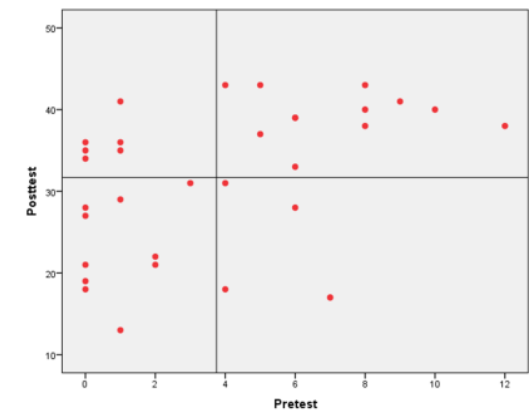

(a)

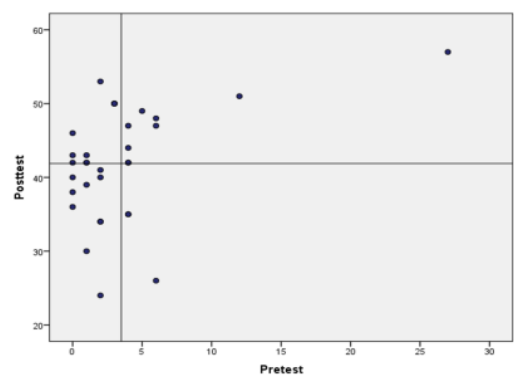

(b)

Gambar 1. (a) Diagram Pencar Skor Pretest-Posttest Kelas Kontrol, (b) Diagram Pencar Pretest-Posttest Kelas Eksperimen

Beberapa titik menunjukkan sebagian siswa yang memperoleh skor pretest rendah ternyata memperoleh nilai $N$-Gain yang baik. Hal ini menunjukkan bahwa siswa yang sebelumnya memiliki kemampuan pemecahan masalah yang rendah, siswa tersebut mengalami peningkatan kemampuan pemecahan masalah setelah diberikan perlakuan. Namun apabila dibandingkan, kelas eksperimen memiliki peningkatan yang lebih tinggi dibanding kelas kontrol. Hal ini dikarenakan siswa kelas eksperimen lebih terlatih dalam mengontrol aktivitas metakognisinya dalam memecahkan suatu permasalahan jika dibandingkan dengan kelas kontrol.

Berdasarkan hasil penelitian yang disajikan pada tendensi sentral, ukuran dispersi, ukuran letak, serta diagram pencar menunjukkan terjadinya peningkatan kemampuan pemecahan masalah pada

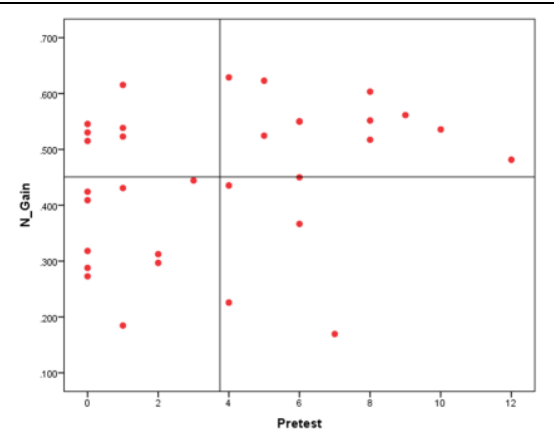

(a)

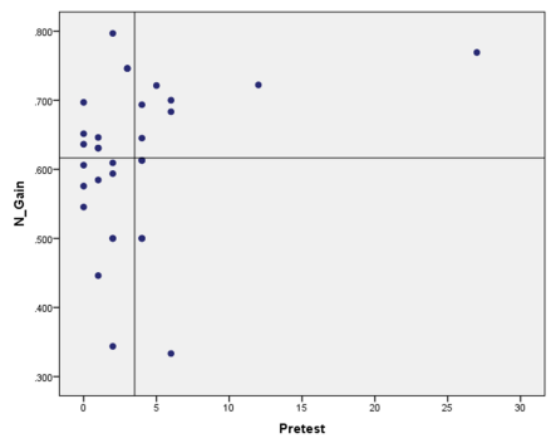

(b)

Gambar 2. (a) Diagram Pencar Skor Pretest- $N$-Gain Kelas Kontrol, (b) Diagram Pencar Pretest- $N$-Gain Kelas Eksperimen

kedua kelas setelah diberi perlakuan. Berdasarkan hasil yang diperoleh, peningkatan kelas eksperimen lebih tinggi dibandingkan kelas kontrol. Hal ini berarti strategi pembelajaran metakognisi lebih baik daripada strategi pembelajaran ekspositori dalam meningkatkan kemampuan pemecahan masalah.

Strategi pembelajaran metakognisi yang diterapkan pada kelas eksperimen membantu dalam memberdayakan metakognisi siswa, sehingga kemampuan pemecahan masalahnya juga lebih baik. Hal ini didukung oleh penelitian Ozsoy et.al (2009) yang menyatakan bahwa siswa yang memiliki metakognisi tinggi lebih berhasil dalam mengarahkan proses belajarnya. Hasil penelitian juga sejalan dengan pernyataan Pemberdayaan metakognisi siswa ini dapat terlihat pada langkahlangkah pembelajaran strategi metakognisi yang diterapkan. 
Pada tahap mengidentifikasi apa yang diketahui dan apa yang tidak diketahui, guru memberikan apersepsi berupa permasalahan yang menjadi bahan diskusi untuk mengetahui apa yang sudah diketahui dan apa yang belum diketahui siswa. Siswa akan menanggapi apersepsi tersebut dengan cara menghubungkan pada konsep atau pengetahuan awal yang dimiliki siswa (Mariati et.al, 2017). Berdasarkan jawaban tersebut, guru dapat mengetahui kemampuan awal siswa untuk selanjutnya diarahkan ke tujuan belajar yang akan dicapai.

Proses beripikir siswa untuk memahami materi juga dapat diarahkan dengan bantuan LKPD pada tahap berbicara tentang berpikir. Sebagai contoh, proses berpikir siswa dalam mempelajari Hukum Gay Lussac diarahkan dengan pertanyaan, "Bagaimana hubungan antara tekanan gas ideal dengan suhu gas ideal pada saat volume gas ideal konstan?". LKPD tersebut juga disertai contoh permasalahan. Ketika siswa sedang berusaha memahami masalah, guru menyampaikan beberapa pernyataan yang dapat menumbuhkan kesadaran siswa dalam menyusun rencana atau strategi dalam menyelesaikan masalah. Ketika membahas solusi masalah, guru memberikan peringatan atas jawaban yang siswa kerjakan. Adanya peringatan tersebut merangsang siswa untuk mengevaluasi hasil pekerjaannya. Pemecahan masalah secara bersama merupakan strategi yang baik. Seorang siswa akan membicarakan suatu masalah serta menguraikan proses berpikirnya. Sedangkan siswa lain akan mendengarkan dan membantu memperjelas pemikirannya (Blakey \& Spence, 1990).

Siswa juga diajak untuk merefleksikan proses berpikir yang telah dilakukan dengan bantuan jurnal berpikir. Contoh jurnal berpikir yang dibuat siswa ditunjukkan Gambar 3. Pertanyaan nomor tiga pada gambar 3 berhubungan dengan kemampuan pemecahan masalah siswa. Pada pertanyaan tersebut, siswa menjawab "Belum hafal rumus". Jawaban tersebut menunjukkan siswa mengalami kesulitan dalam pemecahan masalah tahap kedua, yaitu merancang rencana penyelesaian. Pada tahap merancang rencana ini memang siswa dituntut untuk bisa memilih konsep ataupun persamaan yang dapat menyelesaikan suatu masalah. Hal ini penting karena menjadi kunci dalam proses pemecahan masalah.

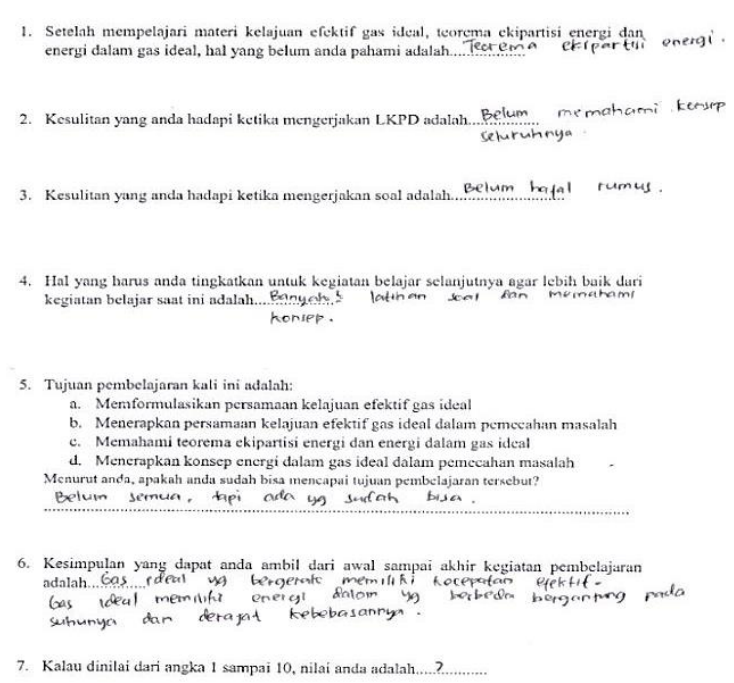

Gambar 3. Jurnal Berpikir Siswa pada Strategi Metakognisi

Guru membantu siswa dalam perencanaan dan regulasi diri melalui jurnal berpikir ini. Berdasarkan jurnal berpikir pada gambar 3, siswa meregulasi dirinya dan menyadari bahwa siswa tersebut menghadapi kesulitan pada langkah merancang rencana penyelesaian. Selanjutnya guru berperan membantu dalam perencanaan proses berpikir siswa dengan memberikan pernyataan atau pertanyaan, seperti, "Coba pahami baik-baik besaran apa saja yang ada pada materi tersebut. Temukan hubungan antara besaran yang ada pada persamaan dan terjemahkan dengan bahasamu sendiri. Selanjutnya banyak berlatih mengerjakan soal". Pertanyaan dan pernyataan tersebut diberikan agar siswa terpicu untuk membuat langkah-langkah perencanaan berpikir dalam usahanya memahami persamaan. Guru memfokuskan diskusi jurnal siswa untuk mengevaluasi keberhasilan pembelajaran. Berdasarkan beberapa jurnal berpikir yang telah dibuat, siswa dapat mengevaluasi keberhasilan pembelajaran dari pertemuan awal hingga akhir.

Pada kelas kontrol diterapkan strategi pembelajaran ekspositori. Menurut Sanjaya (2007), strategi pembelajaran ekspositori memiliki beberapa karakteristik yaitu: Pertama, penyampaian materi dilakukan secara lisan. Kedua, materi pembelajaran merupakan materi pelajaran yang 
harus dihafal, sehingga tidak menuntut peserta didik untuk berpikir ulang. Ketiga, tujuan utama pembelajaran adalah peserta didik dapat memahami materi dan dapat mengungkapkan kembali materi yang telah disampaikan

Perbedaan perlakuan yang diberikan mengakibatkan perbedaan peningkatan kemampuan pemecahan masalah kedua kelas. Strategi pembelajaran metakognisi memfasilitasi siswa dalam mengontrol proses berpikirnya, sehingga proses pemecahan masalahnya dapat terarah. Pengontrolan aktivitas berpikir tersebut dipicu dengan pertanyaan maupun pernyataan yang diberikan guru. Selain itu, strategi pembelajaran metakognisi memberikan kesempatan kepada siswa untuk merefleksikan kembali proses berpikir yang telah dilakukan. Refleksi ini penting dalam mengevaluasi proses pembelajaran, sehingga siswa dapat mengetahui kekurangan yang ada pada diri siswa dalam proses memecahkan masalah. Hal ini berbeda dengan strategi ekspositori yang tidak memfasilitasi kontrol proses berpikir serta tidak memberikan kesempatan bagi siswa untuk merefleksikan proses berpikir dalam memecahkan masalah yang telah dilakukan. Oleh karena itu, proses pemecahan masalahnya kurang terarah.

Hal ini diperkuat dengan perbedaan hasil jawaban siswa pada saat posttest dibandingkan pretest. Sebagai contoh, hasil jawaban siswa saat pretest yang memiliki skor sama pada soal nomor, yaitu mengenai energi dalam gas ideal. Berdasarkan hasil jawaban, siswa kelas kontrol maupun kelas eksperimen dapat menuliskan langkah pertama pemecahan masalah dengan baik. Keduanya mampu menuliskan apa yang diketahui dan apa yang ditanyakan dengan tepat. Pada soal nomor 6 dapat diketahui bahwa terdapat dua jenis gas yang berbeda, yaitu Hidrogen $\left(\mathrm{H}_{2}\right)$ dan Argon (Ar) yang memiliki suhu sama. Kedua gas tersebut memiliki jumlah mol yang sama. Sedangkan yang menjadi pertanyaan adalah apakah kedua gas tersebut memiliki energi dalam yang sama atau tidak.

Pada pretest ini, siswa kelas kontrol dan kelas eksperimen hanya mampu mengerjakan sampai langkah pertama saja, yaitu memahami masalah. Siswa tidak menuliskan langkah berikutnya, yaitu merancang rencana. Hal ini bisa diakibatkan karena kedua siswa belum menerima materi tentang energi dalam gas ideal. Kedua siswa tidak dapat memilih persamaan yang dapat membantu menyelesaikan permasalahan itu. Oleh karena itu, langkah-langkah penyelesaian selanjutnya juga tidak bisa dilaksanakan oleh mereka.

\section{Terdapat cua buah tabung berisi gas hidrogen $\left(\mathrm{H}_{2}\right)$ dan gas argon (Ar). Kedua gas tersebut memiliki suhu yang sama, yaitu $400^{\circ} \mathrm{C}$. Kedua gas tersebut juga memilikj jumlah mol yang sama. Apakah kecua gas tersebut juga memiliki besar energi dalam yang sama?}

\section{Gambar 4. Soal Posttest Nomor 6}

Pada saat posttest, siswa mengerjakan soal dengan indikator yang sama namun dengan beberapa variabel yang berbeda. Sebagai contoh pada soal nomor 6 yang disajikan gambar 4, yaitu mengenai energi dalam gas ideal.

Dari hasil posttest tersebut, terlihat perbedaan peningkatan kemampuan pemecahan masalah kedua siswa. Siswa kelas kontrol maupun kelas eksperimen dapat menuliskan langkah pertama pemecahan masalah dengan baik, seperti halnya saat pretest. Keduanya mampu menuliskan apa yang diketahui dan apa yang ditanyakan dengan tepat. Pada soal nomor 6 yang disajikan pada gambar 4, dapat diketahui bahwa terdapat dua jenis gas yang berbeda, yaitu Helium (He) dan Nitrogen $\left(\mathrm{N}_{2}\right)$ yang memiliki suhu sama. Keduanya juga mengkonversi satuan suhu dari Celcius ke Kelvin. Kedua gas tersebut memiliki jumlah partikel $(N)$ yang sama. Sedangkan yang menjadi pertanyaan adalah manakah diantara kedua gas tersebut yang memiliki energi dalam paling besar.

Pada tahap kedua, siswa memilih persamaan ataupun konsep yang diperlukan untuk menyelesaian suatu permasalahan. Pada Gambar 5 (a), disajikan hasil jawaban siswa kelas kontrol.

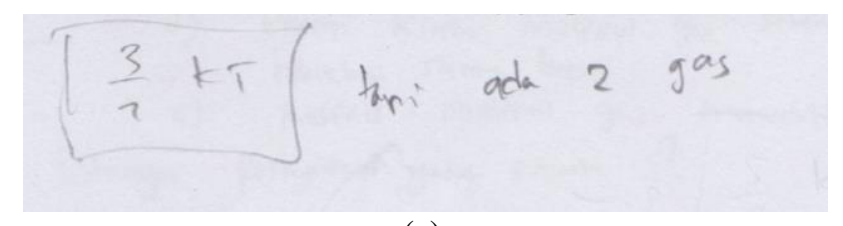

Gambar 5. (a) Hasil Jawaban Posttest Kelas Kontrol Langkah Kedua

Siswa dari kelas kontrol merancang rencana penyelesaian dengan menuliskan persamaan $\frac{3}{2} k T$ untuk menyelesaikan permasalahan tersebut. Persamaan tersebut hampir tepat untuk 
menyelesaikan soal nomor 6. Kesalahan pertama, persamaan tersebut tidak menyertakan variabel $\mathrm{N}$ (Jumlah partikel gas). Kesalahan yang kedua, siswa tersebut tidak memperhatikan derajat kebebasan (f) kedua gas. Pada suhu $573 \mathrm{~K}$, gas helium (monoatomik) memiliki 3 derajat kebebasan. Sedangkan gas nitrogen memiliki 5 derajat kebebasan. Berdasarkan persamaan dasar $U=\frac{f}{2} N k T$, maka persamaan yang cocok untuk gas helium adalah $U=\frac{3}{2} N k T$ dan persamaan yang cocok untuk gas nitrogem adalah $U=\frac{5}{2} N k T$. Hasil jawaban berbeda ditunjukkan oleh siswa kelas eksperimen. Siswa kelas eksperimen dapat merancang rencana penyelesaian masalah secara sempurna, seperti yang ditunjukkan oleh Gambar 5 (b).

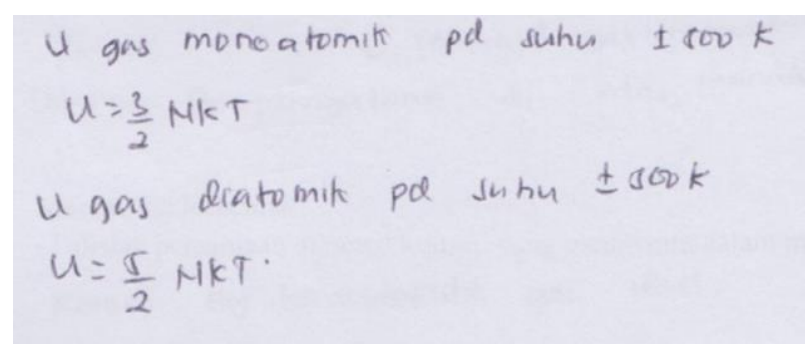

(b)

Gambar 5. (b) Hasil Jawaban Postest Kelas Eksperimen Langkah

Terlihat bahwa siswa tersebut mampu memilih persamaan yang tepat untuk menyelesaikan soal nomor 6 yang ditampilkan pada gambar 4. Siswa kelas eksperimen dapat memilih persamaan untuk mencari energi dalam berdasarkan apa yang diketahui dari soal. Pada soal nomor 6 yang diketahui adalah jumlah partikel gas $(N)$, maka dipilihlah persamaan $U=\frac{f}{2} N k T$. Selain itu, siswa kelas eksperimen mampu membedakan persamaan untuk gas monoatomik dan gas diatomik pada suhu 573 K. Siswa tersebut menyadari bahwa pada suhu tersebut gas monoatomik 3 derajat kebebasan dan gas diatomik memiliki 5 derajat kebebasan.

Adanya perbedaan kemampuan pemecahan masalah pada langkah kedua ini dipengaruhi oleh kegiatan pembelajaran yang dilakukan. Pada saat kegiatan pembelajaran dengan strategi metakognisi berlangsung, guru memberikan pernyataanpernyataan yang dapat membangunkan kesadaran siswa untuk merancang rencana penyelesaian dengan tepat. Sedangkan pada kelas kontrol, saat pembelajaran dengan strategi ekspositori berlangsung, guru tidak memberikan pernyataanpernyataan sebagaimana kelas eksperimen. Oleh karena itu, kesadaran siswa kontrol dalam merancang rencana belum terbangun dengan baik.

Pada langkah ketiga, siswa berusaha memecahkan permasalahan yang dihadapi dengan rencana yang telah ditentukan sebelumnya. Siswa kelas kontrol tidak menemukan solusi atas permasalahan dengan tepat, sebagaimana ditampilkan gambar 6 (a).

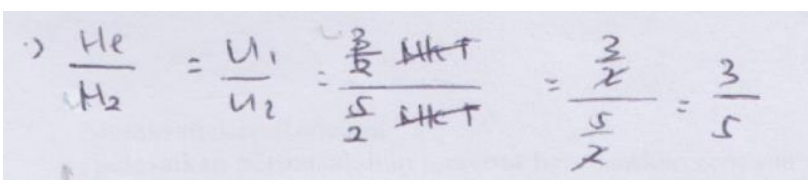

Gambar 6. (b) Hasil Jawaban Postest Kelas Eksperimen Langkah Ketiga

Siswa terlihat mampu dalam melaksanakan rencana yang telah dirancang sebelumnya. Siswa menyelesaikan permasalahan dengan membandingkan persamaan energi dalam gas monoatomik (gas helium) dan persamaan energi dalam gas diatomik (gas nitrogen) pada suhu $573 \mathrm{~K}$ secara tepat. Ketika mengoperasikan kedua persamaan tersebut, siswa telah melaksanakannya dengan baik dan teliti. Oleh karena itu, siswa kelas eksperimen dapat memperoleh solusi yang tepat berupa perbandingan energi dalam gas helium dan gas nitrogen. Hal ini sejalan dengan hasil penelitian yang dilakukan oleh Permata et.al (2012) bahwa strategi metakognisi berpengaruh menonjol pada aspek melaksanakan rencana penyelesaian masalah matematika.

Perbedaan kemampuan pemecahan masalah pada langkah ketiga ini disebabkan perbedaan kegiatan pembelajaran yang dilakukan antara kelas eksperimen dan kelas kontrol. Pengalaman metakognisi berupa pemantauan melalui pemberian peringatan menjadi komponen penting dalam pemecahan masalah. Siswa akan berpikir kembali mengenai kebenaran persamaan, konsep, dan perhitungan dalam proses pemecahan masalah hingga menemukan solusi (Ali et.al, 2016), guru memberikan peringatan-peringatan yang membantu 
siswa meminimalisir kesalahan dalam melaksanakan rencana penyelesaian.

Adanya peringatan tersebut juga memicu siswa untuk memantau proses berpikirnya dalam menyelesaikan permasalahan tersebut. Berbeda halnya dengan pembelajaran kelas kontrol, guru tidak memberikan peringatan apapun ketika siswa berlatih mengerjakan soal. Hal ini mengakibatkan siswa mempunyai peluang melakukan kesalahan lebih besar dalam melaksanakan rencana penyelesaian.

Pada tahap terakhir, siswa perlu menuliskan kesimpulan yang dapat menjawab pertanyaan yang ada pada soal. Berdasarkan hasil jawaban posttest, siswa kelas kontrol tidak menuliskan kesimpulan berdasarkan solusi yang tepat. Solusi tersebut menjadi dasar dalam pengambilan kesimpulan. Solusi akhir dalam permasalahan tersebut adalah ditemukannya perbandingan energi dalam kedua gas. Hasil yang berbeda ditunjukkan pada hasil jawaban posttest kelas eksperimen. Siswa tersebut dapat menuliskan kesimpulan jawaban dengan tepat berdasarkan solusi yang tepat pula. Kesimpulan tersebut dapat menjawab pertanyaan pada soal nomor 6, yaitu "Diantara kedua gas tersebut, manakah gas yang memiliki energi dalam yang paling besar?'. Hasil penelitian sejalan dengan pernyataan Mariati (2012) bahwa kemampuan metakognisi membantu dalam mengonstruksi pengetahuan, mengaplikasikan dan memperdalam konsep-konsep fisika sehingga memunculkan jawaban ilmiah yang merepresentasikan pemahaman. Pada pembelajaran di kelas eksperimen guru memberikan penekanan yang membantu siswa mengevaluasi hasil pekerjaannya. Sedangkan di kelas kontrol guru tidak memberikan penekanan yang dapat merangsang siswa untuk meninjau kembali pekerjaannya.

Berdasarkan pemaparan di atas, kelas eksperimen memiliki kemampuan pemecahan masalah lebih tinggi dibandingkan kelas kontrol. Hal ini dibuktikan dengan nilai $N$-Gain yang dimiliki kelas eksperimen lebih tinggi dari kelas kontrol. Oleh karena itu, strategi pembelajaran metakognisi terbukti lebih baik dalam meningkatkan kemampuan pemecahan masalah siswa dibandingkan strategi pembelajaran ekspositori.
Penerapan pembelajaran yang dilakukan pada kedua kelas tentunya tak terlepas dari kendala yang muncul. Pertama, jumlah jam pelajaran tidak ideal. Hal ini juga menyebabkan waktu yang dialokasikan untuk membuat dan mendiskusikan jurnal berpikir pada kelas eksperimen terlalu singkat. Kedua, sulitnya pengondisian siswa pada kedua kelas. Hal ini diperkuat dengan hasil observasi aktivitas siswa. Pada kelas kontrol dan eksperimen, siswa kurang memfokuskan dirinya untuk mengikuti pembelajaran.

Setelah beberapa pertemuan, siswa kelas kontrol masih sangat bergantung kepada guru saat berlatih mengerjakan soal. Siswa masih cenderung menunggu guru untuk memberikan petunjukpetunjuk dalam mengerjakan soal tersebut. Hal ini berbeda dengan siswa kelas eksperimen. Siswa kelas eksperimen lebih terbangun kesadaran berpikirnya, sehingga dengan sendirinya dapat menyelesaikan soal tersebut sesuai dengan langkah penyelesaian yang benar. Kesadaran berpikir tersebut merupakan motivasi intrinsik dalam proses belajar siswa. Hal ini sejalan dengan hasil penelitian Utaminingsih (2017), bahwa semakin tinggi metakognisi siswa maka motivasi belajarnya juga semakin tinggi.

\section{PENUTUP}

Berdasarkan hasil penelitian yang diperoleh, strategi pembelajaran metakognisi berpengaruh terhadap kemampuan pemecahan masalah siswa. Peningkatan kemampuan pemecahan masalah siswa yang mengikuti pembelajaran dengan strategi metakognisi lebih tinggi dibandingkan siswa yang mengikuti pembelajaran dengan strategi ekspositori. Disarankan bagi guru fisika yang akan mengembangkan jurnal berpikir, perlu memilih pertanyaan-pertanyaan yang dapat merangsang siswa mengevaluasi proses berpikirnya serta disesuaikan dengan pembelajaran yang telat dilaksanakan. Bagi penelitian selanjutnya, disarankan untuk menambahkan instrumen wawancara dalam penelitian, sehingga peneliti dapat mengetahui proses berpikir siswa dalam memecahkan masalah secara lebih detail. 


\section{DAFTAR PUSTAKA}

Ali, Marline et.al. 2016. The Importance of Monitoring Skills in Physics Problem Solving. European Journal of Education Studies Volume 1 Issue 3, 1-10

Anderson, Lorin W. \& David R. Krathwohl. 2010. Kerangka Landasan Untuk Pembelajaran, Pengajaran, dan Asesmen Revisi Taksonomi Pendidikan Bloom. Terjemahan oleh Agung Prihantoro. 2010 .Yogyakarta: Pustaka Pelajar.

Anggo, Mustamin. 2011. Pelibatan Metakognisi Dalam Pemecahan Masalah Matematika. Jurnal Edumatica Volume 01 Nomor 01.

Blakey, Elaine \& Sheila Spence. 1990. Developing Metacognition. New York: ERIC Clearinghouse on Information Resources Syracusa NY.

Flavell, John H. 1979. Metacognition and Cognitive Monitoring: A New Area of CognitiveDevelopmental Inquiry. American Psychological Association, Volume 34, No.10, 906-911

Hake R.R. (1998). Interactive-Engagement Versus Traditional Metode: A Six-ThousandStudent Survey Of Mechanics Test Data For Introductory Physics Courses. American Journal of Physics, 66 (1), pp. 67-74.

Jayapraba, G. \& M. Kanmani. 2013. Metacognitive Awareness in Science Classroom of Higher Secondary Student. International Journal of New Trends in Education and Their Implication Volume: 4, Issue: 3, Article: 07

Latipah, Eva. 2012. Pengantar Psikologi Pendidikan. Yogyakarta : Pedagogia.

Mahmudah, Isni Rifa'atul. 2013. Analisis Kesalahan dalam Menyelesaikan Soal Materi Pokok Teori Kinetik Gas pada Siswa Kelas XI SMA Negeri 7 Surakarta Tahun Ajaran 2012/2013. Skripsi, tidak diterbitkan. Solo: UNS

Mariati, P.S. 2012. Pengembangan Model Pembelajaran Fisika Berbasis Problem Solving untuk Meningkatkan Kemampuan
Metakognisi dan Pemahaman Konsep Mahasiswa. Jurnal Pendidikan Fisika Indonesia Volume 8 (2), 152-160

Mariati, P.S. et.al. 2017. The Problem Solving Learning Model by Using Video Recording on Experiments of Kinematics and Dynamics to Improve The Students Cognition and Metacognition. Jurnal Pendidikan Fisika Indonesia Volume 13 (1), 25-32

Nugrahaningsih, Theresia Kriswianti. 2012. Metakognisi Siswa Kelas Akselerasi dalam Menyelesaikan Masalah Matematika. Jurnal Magistra No. 82 Th. XXIV, 37-50

Ozsoy, Gokhan et.al. 2009. Metcognition, Study Habits and Attitudes. International Electronic Journal of Elementary Education, Volume 2 Issue 1, 154-166

Permata, Siska Putri et.al. 2012. Penerapan Strategi Metakognitif Dalam Pembelajaran Matematika Siswa Kelas X SMA Negeri 2 Padang. Jurnal Pendidikan Matematika, Volume 1 no. 10

Polya, George. 1973. How to Solve It Second Edition. New Jersey: Princeton University Press

Sanjaya, Wina. 2007. Strategi Pembelajaran Berorientasi Standar Pendidikan. Jakarta: Kencana

Schraw, Gregory \& David Moshman. 1995.

Metacognitive Theories. Educational

Psychology Review 7:4, pp: 351-371

Utaminingsih, Diah. 2017. Studi Hubungan Antara Metakognisi, Self-Regulasi dan Motivasi Belajar Siswa. Jurnal Pendidikan Progresif. Volume 3 No. 1

Wahyuddin. 2016. Pengaruh Metakognisi, Motivasi Belajar, dan Kreativitas Belajar Terhadap Kemampuan Pemecahan Masalah Siswa Kelas VIII SMP Negeri 2 Sabbangparu Kabupaten Wajo. Jurnal Daya Matematis, Volume 4 No. 1 